\title{
MOTIVASI DOSEN: Bekerja hingga Ibadah (Studi pada Dosen Program Studi Manajemen Universitas Islam Indonesia)
}

\author{
Putri Oktovita Sari ${ }^{1}$ \\ Robby Sandhi Dessyarti ${ }^{2}$ \\ Fakultas Ekonomi dan Bisnis, Universitas PGRI Madiun \\ E-mail : putrioktovia@unipma.ac.id \\ robbeyvan@gmail.com
}

\begin{abstract}
The objective of this research is to descripe lecturer's motivation in work which is assessed by teaching and learning process. Lecturer's motivation consists of intrinsic and extrinsic encouragement. Intrinsic encouragement is more directed at nonfinancial aspects (worship, pleasure). While extrinsic motivation is more directed at financial aspects (position). This research use qualitative approach with the number of respondents as much four lecturers of Management Department of Universitas Islam Indonesia. Sample is selected by purposive sampling. The sample is determined based on criteria determined by researcher. The results of this research indicate that the lecturers have different motivations in carrying out their profession. The motivation of a lecturer is more towards non-financial aspects, a job that is liked, work as a worship, work as a career and work as a pleasure that grows out of compulsion. This research also found evidence that financial will not always provide encouragement for someone. Motivation is very important because it is closely to the performance of the lecturer. Lecturers who have high motivation will exert their thoughts and energy to carry out their duties and responsibilities professionally. In other word, the lecturers's motivation is able to encourage their performance.
\end{abstract}

Keywords: Motivation, Lecturer, Performance

\begin{abstract}
ABSTRAK
Penelitian ini bertujuan untuk mendeskripsikan motivasi dosen dalam bekerja yang dinilai dari proses belajar mengajar. Motivasi dosen terdiri dari dorongan intrinsik dan ekstrinsik.Dorongan intrinsik lebih mengarah pada aspek nonfinansial (ibadah, kesenangan).Sedangkan motivasi ekstrinsik lebih mengarah pada aspek finansial (jabatan).Penelitian ini menggunakan pendekatan kualitatif dengan jumlah responden sebanyak empat dosen Program Studi Manajemen Universitas Islam Indonesia. Pemilihan sampel mengunakan purposive sampling.Sampel ditentukan berdasarkan kriteria yang ditentukan oleh peneliti.Hasil penelitian ini menunjukkan bahwa secara umum dosen memiliki motivasi yang berbeda-beda dalam menjalankan profesinya. Motivasi seorang dosen lebih mengarah pada aspek non finansial, yaitu sebagai pekerjaan yang disenangi, pekerjaan sebagai ibadah, pekerjaan sebagai karir dan pekerjaan sebagai kesenangan yang tumbuh dari keterpaksaan. Penelitian ini juga menemukan bukti bahwa finansial tidak selamanya akan memberikan dorongan bagi seseorang. Motivasi sangat penting karena erat hubungannya dengan kinerja dosen. Dosen yang memiliki motivasi yang tinggi maka akan mengerahkan seluruh pikiran dan tenaganya untuk menjalankan tugas dan tanggung jawabnya secara profesional. Dengan kata lain, motivasi dosen mampu mendorong dosen untuk memiliki kinerja yang baik.
\end{abstract}

Kata Kunci: Motivasi, Dosen, Kinerja 


\section{PENDAHULUAN}

Pendidikan merupakan salah satu simbol dari kecerdasaan bangsa. Hal ini menuntut perguruan tinggi sebagai salah satu institusi pendidikan untuk terus melakukan pengembangan kearah yang lebih baik. Data ristekdikti (2018) menunjukkan bahwa hanya sekitar ada $12,17 \%$ tenaga kerja saja yang merupakan lulusan dari perguruan tinggi. Oleh karena itu, perguruan tinggi sebagai pusat pembelajaran harus mampu menghasilkan lulusan yang pandai beradaptasi dan kompetitif. Sehingga lulusan-lulusan yang dihasilkan dapat terserap oleh dunia kerja. Universitas Islam Indonesia (UII) merupakan salah satu universitas swasta di Indonesia yang berbasis Islam yang terus melakukan pengembangan dalam dunia pendidikan untuk mewujudkan visi dalam menghasilkan lulusan berdedikasi, memiliki integritas dan berdaya saing tinggi.

Salah satu program studi yang ada di Universitas Islam Indonesia adalah Program Studi Manajemen. Prodi Manajemen UII merupakan salah satu program studi yang berada dibawah naungan Fakultas Ekonomi dengan Akreditasi A. Program Studi Manajemen UII dalam menjalankan kegiatan operasionalnya seperti pendidikan dan pengajaran selalu menerapkan lima komponen aspek penilaian dimana salahsatunya adalah aspek kualitas dosen. Kualitas dosen merupakan output yang dihasilkan oleh seorang dosen dengan standard yang telah ditentukan oleh masing-masing perguruan tinggi. Selain itu, Kualitas dosen juga dapat diartikan sebagai profesionalisme dosen dalam menjalankan tugas dan tanggung jawabnya sesuai dengan tri dharma perguruan tinggi. Profesionalisme dosen merupakan unsur penting dalam meningkatkan mutu pendidikan melalui transfer ilmu pengetahuan kepada mahasiswa yang pada akhirnya akan memengaruhi mutu lulusan. Mutu lulusan dapat dilihat dengan melakukan evaluasi proses belajar mengajar disetiap akhir semester.

Berkaitan dengan gaya pembelajaran, Handoko (2001) menyatakan, kegiatan belajar mengajar sudah sering dilakukan, namun tidak banyak yang dapat dilihat dari proses kegiatan yang dilakukan pada saat proses belajar mengajar. Proses belajar menjadi sulit diamati dan biasanya hanya diukur melalui hasil yang disebut kinerja dosen. Dalam kaitannya dengan kinerja dosen yang diukur berdasarkan beban kerja dosen yang mencakup kegiatan pokok yaitu: merencanakan pembelajaran, melaksanakan proses pembelajaran, melakukan evaluasi pembelajaran, membimbing 
dan melatih, melakukan penelitian, melakukan pengabdian pada masyarakat dan melakukan tugas tambahan. Kemampuan dosen mengajar merupakan dimensi paling utama untuk dilakukan monitoring. Penilaian ini dapat dilakukan oleh dosen sendiri, Ketua Jurusan dan Manajemen Perguruan Tinggi, maupun oleh peserta didik melalui persepsinya (Magdalena, 2012).

Selain fokus pada kinerja yang dilihat melalui proses belajar mengajar,dosen juga membutuhkan motivasi yang tinggi untuk dapat meningkatkan kinerjanya. Berdasarkan data observasi yang telah dilakukan menunjukkan bahwa lulusan UII khususnya dari Program StudiManajemen mengalami peningkatan mutu yang signifikan dari tahun ke tahun. Hal ini menunjukkan bahwa input dosen berhasil dalam menghasilkan output (lulusan) yang dinamis.

Motivasi yang kuat bagi seorang dosen merupakan faktor yang penting mengingat tuntutan dosen yang berat dalam melaksanakan tugas dan tanggung jawabnya. Setiadi et al (2007) menjelaskan motivasi untuk bekerja merupakan kekuatan individu yang menjadi penyebab timbulnya tingkat, arah, dan presentasi upaya yang dilaksanakan dalam hal bekerja. Gouzaly (2010) menambahkan faktor-faktor motivasi, dipengaruhi dari luar maupun dalam. Dari luar, dipangaruhi oleh bagaimana situasi kerja yang menyenangkan, banyaknya kompensasi yang diberikan oleh organisasi, supervisi yang mengayomi, pemberian penghargaan atas prestasi yang diperoleh karyawan, serta status dan tanggung jawab. Sedangkan motivasi dari dalam adalah lebih menyangkup dorongan yang muncul dari dalam diri individu seperti bagimana kedewasaan seseorang menanggapi sebuah persoalan, tingkat pendidikan, keinginan dan cita-cita pribadi, keperluan, kebosanan dan kelelahan. Selanjutnya Ancok (2001) menambahkan bahwa tingkat religiusitas menjadikan seseorang lebih termotivasi yang didasarkan pada faktor ibadah sebagai kepercayaan terhadap pembalasan Tuhan apabila seseorang melakukan pekerjaan sesuai dengan ajaran perintah agamanya.Faktor religiusitas seseorang turut menjadi faktor pemicu seseorang untuk memiliki kinerja yang baik. Hal ini didasarkan alasan bahwa bekerja merupakan ibadah sehingga harus dikerjakan sebaik mungkin.

Kinerja menjadi penting ketika dikaitkan dengan motivasi bekerja seseorang. Ketika orang termotivasi maka seseorang akan mengarahkan seluruh kemampuannya untuk melakukan pekerjaannya sehingga orang tersebut akan memiliki kinerja sesuai 
dengan keinginan perusahaan atau bahkan lebih produktif pada masa yang akan datang sehingga karyawan, organisasi dan masyarakat dapat memperoleh manfaat (Handoko, 2001).

Obyek penelitian ini adalah Dosen Program Studi Manajemen Fakultas Ekonomi Universitas Islam Indonesia (FE UII). Prestasi akreditasi A yang mampu dipertahankan selama lebih dari dua periode berturut-turut semakin menggenapkan capaian prestasi yang selama ini diraih oleh FE UII, sebagai salah satu fakultas senior di lingkungan UII (FE UII, 2018). Prestasi tersebut tidak lepas dari motivasi dosen dalam mennjalankan tugas dan tanggung jawabnya. Selain motivasi, penelitian ini juga akan mengkaji tentang proses belajar mengajar dosen sebagai representatif dari kinerja. Menurut Knowles et al. (2005), proses belajar mengajar di perguruan tinggi adalah pembelajaran orang dewasa yang disebut dengan istilah andragogi.

Studi tentang proses pembelajaran melalui beberapa metode telah banyak dilakukan, tetapi masih sedikit yang dapat diketahui tentang proses tersebut. Proses yang dinilai sebagai kinerja dosen dalam kegiatan pendidikan dan pengajaran di Perguruan Tinggi. Sesuai argumentasi tersebut maka penelitian ini akan menekankan pada motivasi dosen terhadap kinerja melalui penekanan pada proses belajar mengajar.

\section{TINJAUAN PUSTAKA \\ Kinerja}

Kinerja adalah barometer terkait tindakan yang dilakukan dan tidak dilakukan oleh karyawan (Robbins, 2002). Alwi (2001) mengatakan bahwa kinerja merupakan kualitas perilaku individu atau hasil pecapaian seseorang yang dilihat dari keahlian dan kemampuan individu yang bersangkutan. Dua faktor yaitu keahlian dan kemampuan sangat erat hubungannya dengan kualitas perilaku karyawan dan hasil yang dicapainya. Jenis faktor tersebut yang dimiliki karyawan saling terintegarasi dengan strategi organisasi baik untuk tujuan-tujuan jangka panjang maupun untuk tujuan-tujuan organisasi jangka pendek.

Kinerja dosen merupakan salah satu faktor inti kesuksesan proses kegiatan belajar mengajar di perguruaan tinggi (Pramudyo, 2010). Putri, et al (2012) menambahkan kinerja dosen dapat diukur melalui evaluasi proses belajar mengajar. Dapat disimpulkan bahwa apabila proses belajar mengajar sebagai parameter kinerja dosen apabila dilakukan dengan baik kinerja, maka hal tersebut akan berdampak pada kinerja perguruan tinggi. 


\section{Cara Mengajar}

Kualitas pengajaran harus ditingkatkan karena pendidikan tinggi merupakan kegiatan yang vital (Saestri, 2013). Upaya peningkatan kualitas pembelajaran berarti pula menunjuk pada upaya peningkatan kompetensi tutor secara profesional. Acuan pedagogi dan andragogi digunakan untuk menentukan terpadunya cara mengajar yang dilakukan tutor (Raharjo, 2008). Oleh karena itu menempatkan murid atau siswa pada wadah yang tepat dalam arti nyaman sehingga dapat membentuk mahasiswa yang unggul. Gaya pembelajaran yang kuno dan lebih mengarah ke pemahaman dan menuntut mahasiswa rajin sudah dianggap semu dan tidak efektif. Gaya mengajar saat ini yang diterapkan adalah mengarah pada ajaran andragogi dan bukan pedagogi.

Pendekatan pedagogi merupakan strategi metode pembelajaran dalam pendidikan kesetaraan yang lebih mengarah kepada cara dosen mengajar secara autopilot atau lebih ke traditional methods (Soetarlinah, 1993., Lunandi, 1987). Gaya pembelajaran ini lebih banyak menerjemahkan sejumlah pengalaman dan ketrampilan tanpa pemecahan masalah. Objek yang diterjemahkan dianalisis berdasarkan pemahaman masing-masing anggota. Analisis kemudian dilihat sebagai landasan bagi peserta didik di masa mendatang (Guglielmino et al, 2007).

Sedangkan untuk pendekatan andragogi adalah strategi metode pembelajaran orang dewasa yang berfokus pada proses belajar mengajar yang bersifat lebih terbuka, sejajar, sepadan dan persamaan perilaku kegiatan belajar (Knowles, 2005). Metode ini lebih cocok untuk mengarahkan proses pembelajaran untuk menganalisa, menemukan dan menggunakan hasil temuannya untuk memecahkan sebuah masalah dan berinteraksi secara aktif serta adanya interaksi antara tutor dengan peserta didik. Tutor disini adalah dosen dan peserta didik adalah mahasiswa. Mahasiswa dalam hal ini sudah dikategorikan dewasa. Oleh karena itu, cara mengajar andragogi harus diterapkan.

\section{Motivasi}

Motivasi berasal dari kata "movere" yang berarti dukungan atau penggerak. Motivasi dalam organisasi diberikan hanya untuk sumber daya manusia dari atasan sampai bawahan. Maka dari itu, motivasi sebagai arah untuk mendorong potensi bawahan agar melakukkan pekerjaannya dengan baik sehingga tujuan organisasi yang telah ditentukan dapat terwujud. Lebih lanjut, Handoko (2001) menambahkan motivasi merupakan bentuk dari keinginan seseorang secara pribadi yang merasa terdorong melakukan upaya-upaya tertentu untuk meraih hasil maksimal.

Menurut Hodgetts dan Luthans motivasi diartikan sebagai dorongan melalui proses psikologis seeorang pada saat keinginannya belum terpuaskan. Dorongan tersebut dapat menjadikan sebuah harapan sesorang untuk pencapaian tujuan pribadi atau insentif (Usmara, 2006). Sedangkan Wayne (2008) menambahkan motivasi adalah pemberian dorongan yang menumbuhkan semangat kerja seseorang untuk mau berkolaborasi, produktif dalam bekerja dan saling bersinergi untuk mencapai kepuasan. Berdasarkan beberapa pengertian tersebut dapat disimpulkan motivasi pada dasarnya merupakan sesuatu yang ada di dalam atau diluar diri seseorang yang dapat mendorong 
untuk dapat bekerja giat demi tercapainya kepuasan dan tujuan perusahaan maupun pribadi orang tersebut.

\section{Teori Motivasi}

Teori motivasi yang diterapkan secara tepat sehingga banyak ilmuan yang menekuni kegiatan pengembangan teori. Berikut ini adalah beberapa teori motivasi menurut Hasibuan (2002):

\section{A. Hierarki Teori Kebutuhan (Hierarchical of Needs Theory)}

1. Physicological needs

Kebutuhan fisik yaitu hierarki kebutuhan yang sangat pokok terkait tentang kebutuhan dalam kelangsungan hidup. Kebutuhan ini menyangkut kebutuhan dasar seperti makan, minum, tempat tinggal, udara, dan sebagainya. Kebutuhan dasar tersebut merangsang individu untuk lebih produktif.

2. Safety and Security Needs

Kebutuhan akan rasa aman adalah kebutuhan karyawan dalam melakukan perkerjaan. Karyawan merasa aman dan terhindar dari ancaman kecelakaan kerja sehingga karyawan mau melakukan pekerjaan tersebut. Kemudian, karyawan juga merasa tempat kerja merupakan tempat yang aman untuk menyimpan uang pada waktu kerja.

3. Affiliation or Acceptance Needs

Kebutuhan untuk diterima adalah kebutuhan akan teman, berbagi rasa dan pikiran serta menjalin tali kasih antara satu dengan lainnya. Pada dasarnya manusia tidak bisa hidup secara individual. Manusia lebih suka berkelompok sehingga kebutuhan untuk diterima dalam kelompok menjadi salah satu motivasi seseorang untuk mau mengerjakan tugasnya.

4. Esteem or Status Needs

kebutuhan untuk merasa dihargai dan pengakuan dari karyawan dan masyarakat di lingkungannya. Kebutuhan akan penghargaan ini sebagai bentuk keberhasilan seseorang dalam meraih hasil dari pekerjaannya sehingga mendorong seseorang tersebut untuk terus berprestasi. Harapannya, ketika ia memiliki prestasi yang baik maka semakin tinggi pula prestise dan status seseorang yang di gambarkan dalam banyak hal seperti status sosial (kedudukan dalam masyarakat). 


\section{Self Actualization Needs}

Aktualisasi diri adalah suatu kebutuhan lebih menunjukkan pada keterampilan dan potensi yang dimiliki untuk mencapai prestasi kerja yang sangat memuaskan. Kebutuhan ini terpenuhi dengan menfasilitasi karyawan dengan program pengembangan seperti pendidikan dan pelatihan. Kebutuhan aktualisasi diri lebih pada pemenuhan dari dalam diri seseorang untuk berubah ke arah yang lebih baik dengan memikirkan jenjang karirnya. Semakin tinggi aktualisasi diri seseorang maka semakin tinggi dorongan seseorang untuk mencapai jenjang karir yang lebih tinggi.

\section{Teori Kebutuhan}

Teori kebutuhan mendorong seseorang untuk termotivasi dalam melakukan pekerjaannya. Mc Clelland dalam Robbins (2003) mengungkapkan salah satu dorongan terbesar seseorang adalah keinginan untuk berprestasi. Pada dasarnya seorang individu memiliki cadangan energi potensial yang dapat diubah dan dikembangkan menjadi kekuatan motivasi individu untuk mencapai sebuah kesempatan yang ada. Teori kebutuhan diklasifikasikan menjadi tiga kebutuhan yaitu kebutuhan akan berprestasi, kebutuhan kekuasaan, dan kebutuhan afiliasi. Tiga kebutuhan tersebut ditemukan pada seluruh elemen dalam struktur organisasi. Beberapa karyawan memiliki perpaduan dari ketiga kebutuhan. Pertama, kebutuhan prestasi lebih mengarah pada dorongan untuk mengungguli, dan berprestasi dalam hal standar dan mempunyai usaha lebih secara terus menerus untuk mencapai kesuksesan. kebutuhan ini apabila dikaitkan dengan hierarki Maslow terletak antara kebutuhan akan penghargaan dan aktualisasi diri. Kedua, seorang individu juga membutuhkan kekuasaan untuk memengaruhi orang lain. Tujuan dari kebutuhan kekuasaan adalah untuk membuat orang lain menghargai dan mengakui keberadaan seseorang individu sehingga seorang individu mampu mengendalikan orang lain. Terakhir, kebutuhan seseorang untuk berafiliasi atau bersahabat. Sifat dasar manusia adalah hidup bersama dan berdampingan. Oleh karena itu, kebutuhan untuk berafilasi mampu mendorong keinginan seseorang untuk berhubungan dengan lingkungan sekitarnya. Dorongan tersebut menjadikan seseorang menjalin hubungan 
antar pribadi yang ramah dan akrab. Refleksi dari teori ini adalah keinginan karyawan untuk menciptkan suasana dan kedekatan yang erat dengan lingkungannya, kooperatif dan penuh sikap persahabatan dengan pihak lain.

\section{Teori Religiusitas}

Keberagaman atau religiusitas adalah salah satu dimensi yang digunakan manusia sebagai tolak ukur untuk menjalankan kehidupannya. Aktivitas beragama bukan hanya terjadi ketika seseorang melakukan perilaku ritual (beribadah), tapi juga ketika melakukan aktifitas lain yang didorong oleh kekuatan supranatural. Bukan hanya yang berkaitan dengan aktivitas yang tampak dan dapat dilihat mata, tapi juga aktivitas yang tak tampak dan terjadi dalam hati seseorang. Karena itu keberagaman seseorang akan meliputi berbagai macam sisi atau dimensi.

Menurut Glock \& Stark (Robertson, 1988 dalam Psikologi Islam, 2008), ada lima dimensi keberagaman, yaitu dimensi keyakinan (ideologis), dimensi peribadatan atau praktek agama (ritualistik), dimensi penghayatan (eksperiensial), dimensi pengalaman ( konsekuensial), dimensi pengetahuan agama (intelektual).

1. Dimensi keyakinan

Dimensi ini mengarah pada keyakinan seseorang yang berpedoman hingga berpegang teguh pada suatu pandangan tentang ajaran agama tertentu dan mengakui doktrin-doktrin yang termuat didalamnya.

2. Dimensi praktik agama

Dimensi ini lebih diwujudkan melalui praktik seperti perilaku pemujaan, berdoa, dan hal-hal yang menunjukkan komitmennya terhadap ajaran agama yang dianut. Ada dua kategori kelas praktik, yaitu ritual dan ketaatan dimana mereka berkolaborasi melalui cara-cara masyarakat menyakini dengan melakukan ritual-ritual tertentu mereka dapat berinteraksi dengan Tuhannya. Cara-cara yang dilakukan setiap orang berbeda sesuai dengan kepercayaan dan keyakinan masing-masing individu.

3. Dimensi pengalaman

Pada dimensi ini fakta lebih diperhatikan bahwa suatu agama pasti mengandung sebuah pengharapan tertentu. Pengharapan terebut mengarah pada kepercayaan seseorang ketika ia mengalami dan merasakan bahwa akhirnya sesorang yang beragama baik akan memiliki akhir kehidupan atau mati. 
4. Dimensi pengetahuan agama

Dimensi ini mengacu kepada harapan bahwa orang-orang yang beragama paling tidak memiliki sejumlah minimal pengetahuan mengenai dasar-dasar keyakinan, ritus-ritus, kitab suci, dan tradisi-tradisi.

5. Dimensi konsekuensi atau pertanggung jawaban

Dimensi ini mengacu pada identifikasi akibat keyakinan keagamaan, praktik, pengalaman, dan pengetahuan seseorang dari hari ke hari. Dimensi ini mengajarkan bahwa apa yang dilakukan saat ini nantinya akan dimintai pertanggung jawaban.

\section{METODE PENELITIAN}

\section{Pendekatan Penelitian}

penelitian ini menggunakan pendekatan kualitatif. Penelitian kualitatif adalah penelitian yang menekankan pada kualitas dari hasil instrument dan objek yang diamati. Penelitian kualitatif bertujuan untuk mencari sebuah kejadian atau fenomena penting maupun gejala sosial yang dapat disimpulkan untuk dijadikan sebagai dasar pengembangan konsep teori Satori (2009). Peneliti mengambil lokasi penelitian di Fakultas Ekonomi Prodi Manajemen Universitas Islam Indonesia di Jalan Ring Road Utara, Condong Catur, Depok Sleman, Yogyakarta.

\section{Teknik Pengumpulan Data}

Penelitian ini menggunakan beberapa cara untuk mengumpulkan data, yaitu:

1. Wawancara Terstruktur

Teknik ini dilakukan dengan cara mengumpulkan data melalui proses wawancara yang dilakukan oleh peniliti terhadap responden. Pengumpulan data melalui pertanyaan dari instrumen penelitian yang sebelumnya sudah disusun dengan alternatif jawabannyapun sudah disiapkan. Dengan wawancara terstruktur ini setiap responden diberi pertanyaan yang sama, dan pengumpul data mencatatnya (Sugiyono, 2010).

\section{Observasi Terus Terang}

Peneliti memberikan konfirmasi secara langsung kepada para narasumber bahwa sedang melakukan penelitian dan hasilnya akan digunakan untuk pengembangan teori sehingga narasumber harus melakukan apa adanya. Oleh karena itu, mereka 
yang diteliti mengetahui sejak awal-akhir tentang aktivitas peneliti (Sugiyono, 2010).

\section{Dokumentasi}

Dokumentasi digunakan sebagai bukti pendukung suatu objek pengamatan sehingga akurasinya dapat dikelola dan dijadikan acuan yang lebih detail untuk mengamati sebuah objek. Dokumen diperoleh pada saat dilapangan seperti foto, tulisan, gambar bahkan artefak (Guba dan Lincoln dalam Moleong, 2007).

4. Triangulasi

Triangulasi dalam penelitian dengan pendekatan kualitatif digunakan untuk menguji kredibilitas data. Pengujian kredibilitas diartikan sebagai pengecekan kebenaran dan kesesuaian data dari berbagai sumber dengan berbagai cara dan berbagai waktu. (Sugiyono, 2010).

\section{Teknik Analisis Data}

Menurut Sugiyono (2010) menjelaskan bahwa analisis data dalam penelitian kualitatif dilakukan sebelum melakukan wawancara dan observasi, selama berada di lapangan dan setelah penelitian. Analisis data bertujuan untuk meentukan rumusan masalah dan mengurai fenomena atau masalah yang akan dibahas peneliti. Analisis data yang digunakan dalam penelitian kualitatif ini adalah:

1. Analisis Sebelum Lapangan

Analisis data sebelum memasuki lapangan untuk menentukan fokus penelitian. Data yang digunakan adalah data sekunder untuk melihat kecenderungan gejolak yang menjadi pokok penelitian. Pada saata analisis sebelum lapang ini, fokus penelitian masih bersifat sementara dan akanberkembang setelah penelitian masuk dan selama di lapangan (Sugiyono, 2010).

2. Analisis Selama di Lapangan

Analisis data dilakukan pada saat pengumpulan data berlangsung, dan setelah selesai pengumpulan data dalam periode tertentu. Aktivitas dalam analisis data meliputi data reducsion, data display, dan conclution drawing/verification (Sugiyono, 2010). 


\section{Keabsahan Data}

Keabsahan data menurut Sugiyono (2013) dalam penelitian kualitatif dapat dijelaskan sebagai berikut:

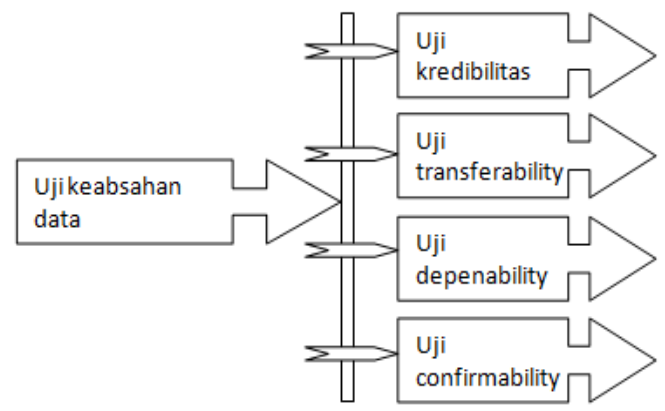

\section{Gambar 1: Uji Keabsahan Data Kualitatif Sumber: Sugiyono (2010)}

\section{HASIL \& PEMBAHASAN}

\section{Penerapan dan Metode Strategi Pembelajaran Aktif}

Dosen Manajemen UII telah berusaha membangun situasi dalam proses belajar mengajarkan dengan menggunakan pendekatan pembelajaran aktif (andragogi). Membangun pendekatan tersebut dengan cara menerapakan berbagai alternatif selain metode ceramah. Berbagai pendekatan yang telah dosen terapkan tersebut adalah sebagai berikut:

\begin{tabular}{|c|c|c|}
\hline Penerapan Strategi & Keterlibatan Mahasiswa & $\begin{array}{l}\text { Metode yang } \\
\text { digunakan }\end{array}$ \\
\hline Group Resume & $\begin{array}{l}\text { - mahasiswa bertukar pendapat } \\
\text { dan pengalaman } \\
\text { - meringkas dan mengambil } \\
\text { pokok-pokok pikiran } \\
\text { - menyimpulkan secara bersama- } \\
\text { sama intisari pelajaran }\end{array}$ & $\begin{array}{l}\text { - diskusi kelompok } \\
\text { - tugas } \\
\text { - kuis berkelompok }\end{array}$ \\
\hline Snowballing & $\begin{array}{l}\text { - menuangkan gagasan individual } \\
\text { - melakukan sharing } \\
\text { - membuat kesimpulan } \\
\text { - melakukan presentasi }\end{array}$ & membahas kasus \\
\hline Problem Solving & $\begin{array}{l}\text { - diskusi untuk pemecahan } \\
\text { masalah } \\
\text { - membuat kesimpulan } \\
\text { - melakukan presentasi } \\
\text { - memberikan feedback }\end{array}$ & $\begin{array}{l}\text { - presentasi kasus } \\
\text { - tambahan poin } \\
\text { untuk mahasiswa } \\
\text { yang aktif } \\
\text { bertanya }\end{array}$ \\
\hline
\end{tabular}

\section{Gambar 2: Penerapan dan Metode Strategi Pembelajaran Aktif} Sumber: Abidin (2005) dan Data Primer Peneliti (2016)

Data diatas menunjukkan bahwa dosen manajemen FE-UII sudah berupaya untuk menerapkan berbagai strategi pembelajaran aktif (active learning). Suasana 
pembelajaran dibuat menjadi interkatif, beragam, menyenangkan dan kondusif untuk belajar mahasiswa. Strategi yang diterapkan yaitu group resume, snowballing, dan problem solving.

\section{Motivasi Dosen}

Saydan dalam Sayuti (2006) megemukakan seseorang akan termotivasi dan mau melakukan pekerjaannya dipengaruhi oleh beberapa faktor, yaitu Faktor internal yang berasal dari proses psikologis dalam diri seseorang dan faktor eksternal yang berasal dari luar diri.

Mahasiswa sebagai pengguna layanan dosen wajar kalau dijadikan sebagai motivasi ekternal dosen. Karena sebagai dosen tanggung jawabnya adalah mengajar, mendidik, membimbing, transfer knowledges dan bahkan membentuk karakter mahasiswa agar kualitas diri dari mahasiswa menjadi baik.

"Selain dosen sebagai pekerjaan kan juga sudah kewajiban juga untuk membimbing mahasiswa dengan baik.Jadi harus berusaha kemudian belajar terus menerus mengembangkan ilmu kemudian diberikan kepada mahasiswa.Ya supaya mahasiswa itu dapat menguassai ilmu yang diberikan dosen." (Bapak Zainal, $25 / 11 / 18,11.15)$

Reputasi dapat dibentuk dari kinerja dosen atau prestasi yang didapat semasa hidupnya.Salah satu prestasi kerja yang dimiliki dosen adalah sebagai dorongan untuk menciptakan reputasi diri.Seorang dosen harus memiliki reputasi yang baik sehingga dapat menjadikan daya tarik bagi mahasiswa.maka dari itu reputasi harus dibangun. Banyak cara dalam membangun reputasi bagi seorang dosen salah satunya dengan mengembangkan secara terus menerus ilmu yang di miliki, berkinerja yang baik dan memiliki dedikasi yang tinggi.

"Dosen itu kan harus memiliki reputasi agar dosen itu bisa menjadi magnet, magnet kan daya tarik.Kalau dosen tidak punya reputasi bagaimana mahasiswa mau tertarik. Nah reputasi itu harus dibangun, setiap dosen memiliki resiko reputasi, kalau dari tahun ketahun ilmunya gak nambah mahsiswanya menganggap sama saja, mahasiswa akan beranggapan kok ini dosen selama bertahun-tahun 
masih sama saja kok tidak ada bedanya. Harus ada pengayaan walaupun ilmu itu memang tidak berubah dengan cepat, tapi kan pendalamannya ada. Maka dari iru dosen harus memiliki reputasi." (Bapak Syafar, 26/10/18, 09.14)

Pada saat dosen sadar pentingnya reputasi bagi dirinya, maka dosen akan melakukan segala upaya untuk mencapai tujuan yang diharapkannya. Bapak Syafar menjadikan reputasi sebagai wujud dari pengakuan seseorang terhadap dirinya.Oleh karena itu, dorongan untuk terus-menerus memperbaiki diri dan melakukan tanggung jawab secara penuh serta memiliki integritas yang tinggi harus dibangun sesuai dengan kapasitas dosen.

Seseorang akan merasa bahwa upayanya akan mengarah pada penyelesaian tugas. Kesadaran diri bahwa penyelesaian tugas akan mengarah pada hasil baik yang berupa status ataupun pengakuan.

"Sukar atau mudah kalau sudah pekerjaan yah harus dijalani dan dikerjakan sampai selesai. Biasanya kan kalau yang menantang itu yang seru. Tapi relatif juga, asal kita selalu mencari yang baru, manajemen itu adalah ilmu yang dinamis, jadi kalau mungkin sejak dulu sampai sekarang yang diajarkan itu-itu saja konteks pembaruhannya apa yang lagi in dan up to date" (Bapak Zainal, 25/10/18, 11.28)

Menurut Fillmore H. Standford dalam Mangkunegara (2000) menyatakan bahwa motivasi akan menggerakkan manusia kearah suatu tujuan tertentu. Dosen akan melakukan segala sesuatu demi tercapainya suatu tujuan baik untuk dirinya sendiri maupun orang lain.

Motivasi dosen memberikan dampak positif pada kinerja dosen bukan hanya di Prodi Manajemen FE-UII saja. Di Universitas Islam 45 (Unisma) motivasi dosen memiliki hasil yang sama yaitu bahwa dosen termotivasi baik dari intrinsiknya maupun ekstrinsiknya dimana motivasi memberikan dorongan untuk melakukan kinerja berupa kompetensi mengajar dan kemampuan mengajar. Dorongan tersebut timbul karena adanya keinginan untuk berprestasi oleh dosen Unisma (Sulastri, 2007). Sedangkan untuk dosen Manajemen UII keinginan berprestasi tidak berdampak terhadap motivasi baik berupa motivasi dari dalam individu maupun dari luar individu itu sendiri. Dilihat 
dari segi track record Universitas, FE UII sudah melalui proses yang panjang dari pada Unisma. Hal ini yang membuat menarik karena dapat dilihat bahwa motivasi seorang dosen timbul karena lamanya dosen bekerja.Apabila dosen di Unisma termotivasi untuk berprestasi karena dosen Unisma masih dibilang dosen baru yang masih fresh dan semangat untuk mencapai tujuan yang bersifat administratif yaitu prestasi.

Dosen FE-UII berdasarkan pengalaman dan track record yang panjang menjadikan para dosen sudah menemukan kepuasannya sepanjang karirnya sehingga dosen yang sudah berpengalaman lebih dari 25 tahun menemukan dorongan lain untuk melakukan pekerjaan dengan sebaik mungkin. Dorongan tersebut adalah non materiil walaupun tidak memungkiri bahwa itu juga memotivasi tapi bukan sebagai hal yang utama.

\section{Cara mengajar (Kinerja Dosen)}

Kemampun dosen dalam menentukan kemampuan mengajar merupakan hal utama dalam pengembangan profesionalisme dosen.Pada setiap perguruan tinggi pastinya memiliki standarisasi dosen dalam mengajar.Ibu Nurul menjadikan itu sebagai standar dalam mengajar.Dimana dosen harus menguasai materi dengan baik, mendorong mahasiswa untuk aktif, membimbing mahasiswa, melakukan diskusi, mengevaluasi hasil ujian dan mengijinkan mahasiswa untuk konsultasi baik didalam maupun diluar kelas.

“yah itu minimal kita begitu dalam mengajar dikelas. Harus cukup bagus lah." (Ibu Nurul, 27/11/18, 10.45)

"Yah kalau kita itu mendidik bukan hanya untuk kita sendiri melainkan juga untuk orang lain. Jadi kalau saya ngerasa kuliahnya gak beres yah harus ada kuliah tambahan. Dan kuliah tambahan itu untuk menanyakan kamu itu mau jadi apa, karena namanya anak orang tuanya gak sempat ngasih tau atau ada problem dengan orang tua yah pastinya kita harus mengayomi ya." (Ibu Janti, 25/11/18, 18.53)

"Kalau Pak Syafar memang cara mengajar beliau seperti anak SMA harus banyak catatan karena memang kalau ujian open book, tapi banyak manfaatnya kok. Jadi 
kalau dikelas mahasiswa itu gak males.Kemudian belajarnya mudah kan dari catatan kita sendiri."(Narasumber G, 30/11/18, 10.13)

Peranan dosen di perguruan tinggi adalah sebagai penyelenggara pembelajaran orang dewasa atau biasa disebut andragogi. Sesuai dengan peran tersebut maka dosen perlu melakukan upaya-upaya penerapan strategi seperti berikut: (1) membuat desain pembelajaran, (2) mempersiapkan alat-alat dan media pembelajaran, (3) menerapkan strategi pembelajaran aktif, dan (4) melakukan evaluasi terhadap proses dan hasil pembelajaran (Abidin, 2005).

\section{SIMPULAN \& SARAN \\ Simpulan}

Berdasarkan analisis yang telah dilakukan, maka kesimpulan yang dapat diambil dari penelitian ini adalah sebagai berikut :

1. Secara umum dosen memiliki motivasi yang berbeda-beda dalam menjalankan profesinya sebagai seorang dosen. Motivasi seorang dosen lebih mengarah pada non finansial, seperti pekerjaan yang disenangi, pekerjaan sebagai ibadah, pekerjaan sebagai karir dan pekerjaan sebagai kesenangan yang tumbuh dari keterpaksaan.

2. Cara mengajar dosen lebih kepada pembelajaran aktif meskipun masih mengarah pada pembelajaran yang bersifat pedagogi atau pembelajaran yang berpusat pada dosen.

\section{Saran}

Obyek penelitian masih terbatas pada dosen Program Studi Manajemen Universitas Islam Indonesia Yogyakarta.Harapannya penelitian selanjutnya bisa dilakukan pada obyek organisasi secara umum atau yang tidak berlatar belakang agama. Dengan demikian akan diketahui apakah ada perbedaan motivasi dosen yang bekerja di sebuah organisasi yang berlatar belakang budaya agama (Islam) dengan motivasi dosen yang bekerja pada sebuah organisasi yang tidak memiliki latar belakang khusus (agama).

\section{DAFTAR PUSTAKA}

Abidin, (2005). Strategi Pembelajaran Di Perguruan Tinggi (Optimalisasi Kinerja Dosen Dalam Pembelajaran Di Fakultas Agama Islam Universitas Muhammadiyah Surakarta). SUHUF, Vol. XVII, No. 01/Mei 2005: 75-85.

Alwi, Safaruddin. (2001). Manajemen Sumberdaya Manusia Strategi Keunggulan Kompetitif. BPFE. Yogyakarta.

Caron and Geli (2004). Taking Back The Law School Classroom: Using Technology To Foster Active Student Learning. Jurnal of Legal Education, Vol. 54 SSRNid527522. 
Guglielmino, L.M., Hillard, L.C. (2007). Self-Directed Learning pf Exemplary Principals. International Journal of Self-Directed Learning: Vol.4 No.2.

Gusti Ayu Made Arna Putri, I Putu Eka Nila Kencana, Komang Gede Sukarsa. (2012). Analisis Kinerja Dosen Jurusan Matematika FMIPA UNUD dengan Metode Chernoff Faces. Vol 1 No 1.

Gouzali, Sadam. (2010). Manajemen Sumber Daya Manusia. (Human Resource) Suatu Pendekatan Mikro. Jakarta: Djambatan.

Handoko, T. Hani. (2001). Manajemen Personalia dan Sumberdaya Manusia. Liberty. Yogyakarta.

Knowles, M.S., Holton, E.F., dan Swanson, R.A. (2005). The Adult Learner: The Definitive Classic in Adult Education and Human Resource Development. California: Elsevier.

Magdalena, Betty. (2012). The Influence of Teaching Empowerment and Motivation towards Lecturers' performance at the Department of Management of IBI Darmajaya Bandar Lampung. Vol 6 No 3.

Pramudyo, Anung. (2010). Analisis Faktor-Faktor yang Mempengaruhi Kinerja Dosen Negeri Pada Kopertis Wilayah V Yogyakarta. JBTI: Vol.1 No.1, Februari 2010.

Raharjo, Suminar (2008). Penerapan Pedagogi dan Andragogi Pada Pembelajaran Pendidikan Kesetaraan Kelompok Belajar Paket A,B, dan C di Kota Semarang. Journal Unnes, Vol, 954.

Ristekdikti (2018). Membangun Indonesia dengan Tenaga Kerja Berkualitas. Diakses pada tanggal 24 Oktober 2018, pukul 10.38 di https://ristekdikti.go.id/kabar/strategi-kemenristekdikti-membangun-indonesiadengan-tenaga-kerja-berkualitas/

Robbins, Stephen P. (2003). Perilaku Organisasi. Jakarta: PT INDEKS Kelompok Gramedia.

Saestri (2013). Penilaian Kinerja Dosen Dengan Menggunakan Metode AHP. Jurnal liquidity: Vol.2, No.1, Januari-Juni 2013: 100-109.

Satori. Djam'an, Aan Komariah. (2009). Metodologi Penelitian Kualitatif. Bandung: Penerbit AlfaBeta.

Sayuti. (2006). Motivasi dan Faktor-faktor yang Mempengaruhi. Jakarta: Penerbit Ghalia.

Setiadi, N.J., Ali, A.A. dan Aafaqi, R. (2007). The Impact of Personal Characteristics and Intrinsic Motivation on Creative Berhavior among Indonesian Radio Station Managers. The South East Asian Journal of Management, Vol,1 No.1.

Sugiyono. (2010). Memahami Penelitian Kualitatif, Wiersma. Penerbit AlfaBeta.

Sulastri, Tuti. (2007). Hubungan Motivasi Berprestasi Dan Disiplin Dengan Kinerja Dosen. Jurnal Optimal Vol. 1, No.1.

Usmara, A. (2006). Motivasi Kerja: Proses, Teori, dan Praktik. Yogyakarta: Amara Books.

Wayne, M.R. (2008). Manajemen Sumber Daya Manusia. Jakarta: Erlangga. 